\title{
PROJETO CR298: ALTAS TAXAS DE INJEÇÃO DE CARVÃO PCI COM BAIXO FUEL RATE NOS ALTOS FORNOS DA ARCELORMITTAL TUBARÃO*
}

\author{
Filipe Sathler ${ }^{1}$ \\ Ramiro da Conceição do Nascimento Junior ${ }^{2}$ \\ Leonardo Passos Perdigão ${ }^{3}$ \\ Estefan Campos Ribeiro ${ }^{4}$ \\ Luiz Augusto Wasem ${ }^{5}$
}

\section{Resumo}

O projeto CR298 se iniciou no final do segundo semestre de 2014 quando o Coque Rate (CR) médio era de $351,0 \mathrm{~kg} / \mathrm{t}$. A meta definida foi de atingir média mensal de CR de $298 \mathrm{~kg} / \mathrm{t}$ em dezembro de 2016, permitindo aumento de produção com alta taxa de injeção de carvão $\mathrm{PCl}$, porém, com baixo Fuel Rate, garantindo competitividade de mercado. Sendo assim, foi desenvolvido e divulgado um novo modelo mental de operação, processo, manutenção e gestão, envolvendo toda a área de Redução, Utilidades e Aciaria. Várias premissas técnicas foram estabelecidas com um plano de ação detalhado para garantir estabilidade no processo dos altos fornos de forma a obter este resultado. A meta foi atingida antes mesmo do planejado: CR 291,3 kg/t em Maio de 2016 e em 2016 a média anual foi de 297,0 kg/t, com Fuel Rate de 484,4 kg/t.

Palavras-chave: Alto Forno; Coque Rate; PCl; Altas Taxas de Injeção; Fuel Rate.

\section{PROJECT CR298: HIGH PC INJECTION RATE WITH LOW FUEL RATE IN ARCELORMITTAL BLAST FURNACES}

\section{Abstract}

The project CR298 started at second half of 2014 when Coke Rate annual average was $351,0 \mathrm{~kg} / \mathrm{t}$. The target was to achieve sustainably Coke Rate monthly average below $298 \mathrm{~kg} / \mathrm{t}$ in December 2016, maximizing production with high pulverized coal injection (PCl) rate but low Fuel Rate to guarantee market competitiveness. Hence, it was necessary to develop and spread a new mind set in operation, process, maintenance and management involving all Ironmaking, Energy and Steel Areas. Some technical premises were stablished with a detailed action plan to ensure the operational and process blast furnaces stability in order to obtain the proposed results. The target was achieved before than planned: CR 291,3 kg/t in May 2016 and the 2016 annual average was 297,0 kg/t with Fuel Rate 484,4 kg/t. Therefore, it was a successful project that continues in constant improvement.

Keywords: Blast Furnace; Coke Rate; PCl; High Injection; Fuel Rate.

1 Engenharia Metalúrgica, Especialista de Altos Fornos, Unidade Técnica da Área de Redução, ArcelorMittal Tubarão, Serra, Espírito Santo, Brasil.

2 Engenharia Metalúrgica e de Materiais, Pós-Doutorado, Professor, Departamento de Metalurgia e Materiais, Instituto Federal do Espírito Santo (IFES), Vitória, Espírito Santo, Brasil.

3 Engenharia Metalúrgica, Gerente da Unidade Técnica da Área de Redução, ArcelorMittal Tubarão, Serra, Espírito Santo, Brasil.

4 Engenharia Metalúrgica, Especialista de Altos Fornos, Unidade Técnica da Área de Redução, ArcelorMittal Tubarão, Serra, Espírito Santo, Brasil.

5 Engenharia Metalúrgica, Especialista de Altos Fornos, Unidade Técnica da Área de Redução, ArcelorMittal Tubarão, Serra, Espírito Santo, Brasil. 


\section{INTRODUÇÃO}

$\mathrm{Na}$ atual conjuntura do mercado siderúrgico, nota-se uma grande necessidade de redução de custos operacionais para garantia de competitividade. Apesar das especificidades de cada empresa, o custo do ferro gusa normalmente consiste em um dos principais fatores que impactam nessa demanda [1]. Para isso, busca-se a excelência operacional dos altos fornos de forma a permitir, dentre outros ganhos, a redução do consumo de combustíveis [1].

Nos altos fornos a coque, a grande maioria das empresas pratica injeção de carvão pulverizado nas ventaneiras (PCI) para reduzir o consumo de coque e custo de produção $[1,2,3,4]$. O PCl é uma tecnologia praticada há mais de 50 anos, porém, por motivos ambientais e econômicos, nos últimos anos tem-se notado uma tendência para forte elevação das taxas de $\mathrm{PCI}(\mathrm{PCR})$ e redução de Coque Rate (CR), alcançando valores de CR abaixo de $300 \mathrm{~kg} / \mathrm{t}$ e de PCR superiores a $200 \mathrm{~kg} / \mathrm{t}$ por várias empresas ao redor do mundo [2,3].

Entretanto, uma vez que o carvão não consegue cumprir todas as funções do coque, principalmente as de permeabilizar e de suportar a coluna de carga, verifica-se que a partir de certos valores de PCR pode ocorrer diminuição da taxa de substituição do carvão, causando assim a elevação do combustível total (Fuel Rate - FR) e, por isso, deve-se avaliar o custo final $[1,2,3,5,6]$.

Além disso, tecnicamente, com o incremento de PCR e redução do $C R$, ocorre o aumento do tempo de residência do coque ao longo do forno, resultando em maior degradação do coque (geração de finos), principalmente no cadinho e homem morto. Com isso, há também diminuição do comprimento Raceway (zona de combustão) e distúrbios à circulação de líquidos e gás devido menor fração de vazios, conforme mostrado na Figura $1[2,7,8]$. Para maiores taxas de PCR, verificase ainda menor eficiência de combustão do carvão e, portanto, impacto na permeabilidade do forno devido maior presença de finos de carvão não queimados (char) e sua circulação ao longo do forno, causando também incremento da taxa de pó do coletor da limpeza de gás e até riscos de formação de zona inativa na parede do forno $[2,4,9,10]$.

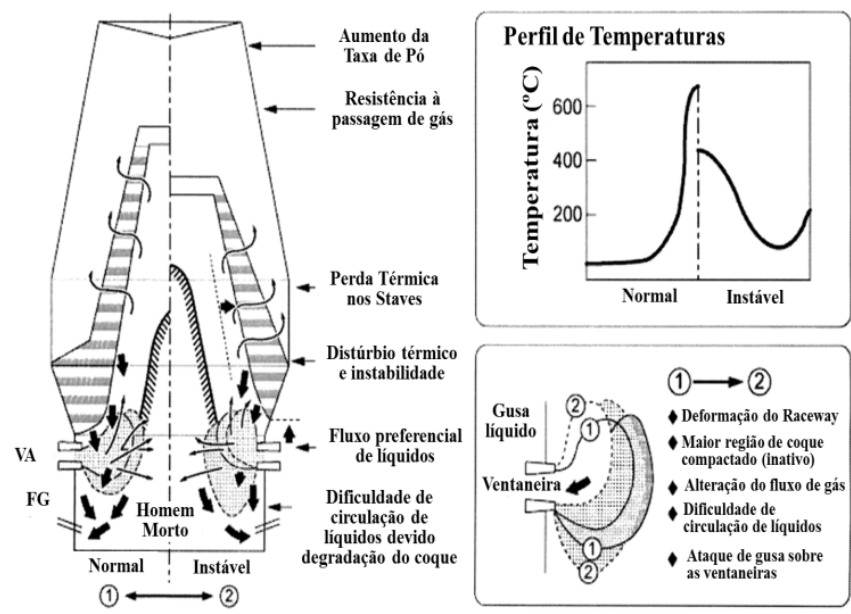

Figura 1. Alterações do fluxo de gás, zona de coesão e de combustão em condições de instabilidade operacional [10].

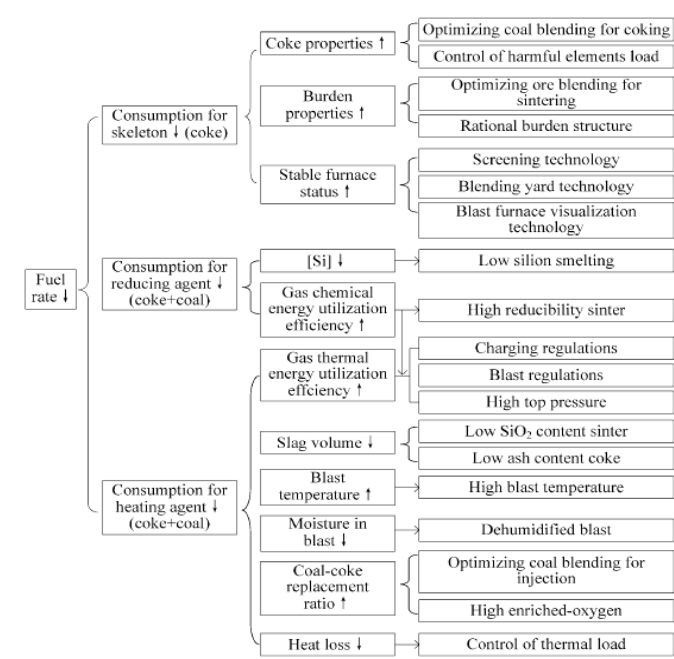

Figura 2. Princípios técnicos para redução do consumo de combustível em altos fornos [1]

Logo, para amenizar esses problemas, melhorias nas áreas de operação, processo, equipamentos, matérias-primas e tecnologias podem ser realizadas para impulsionar o processo de redução de CR e elevação de PCR, assegurando maior estabilidade 
operacional dos altos fornos, maior rendimento de gás CO (ETA CO), melhor permeabilidade, menor volume de escória, menores perdas térmicas e consequente redução do consumo de combustível $[1,2,11]$. Algumas dessas melhorias, mostradas na Figura 2, e outros itens mais, estão detalhados a seguir:

- Melhor Qualidade do Coque: para altas taxas de PCI, o coque precisa manter boas propriedades do topo ao cadinho e, portanto, elevada resistência a frio (Drum Index - DI) e maior resistência após reação (Coke Strenght after Reaction - CSR) [1,2,3,6,7,8,11];

- Menor Volume de Escória: proporciona menor distúrbio à permeabilidade no cadinho (circulação de líquidos), logo, objetiva-se menor $\% \mathrm{SiO}_{2}$ dos minérios, maior \%Fe do sinter, menor \%cinza dos combustíveis [1,2,9,11];

- Espessura da Zona de Coesão: aumentar a temperatura de amolecimento/fusão da carga metálica (controle de redutibilidade), menor delta de temperatura entre início e final de amolecimento/fusão, estabilidade das janelas de coque $[1,2]$;

- Abastecimento: diminuir variações de qualidade química e física pelo controle do abastecimento no pátio de estocagem, da blendagem e do manuseio das matérias-primas [1];

- Peneiramento: reduzir a entrada de finos no alto forno, permitindo maior controle de permeabilidade e estabilidade operacional [1];

- Controle de Álcalis e Zinco: input de álcalis limitado à máximo de 2,0 kg/t e zinco menor que $0,150 \mathrm{~kg} / \mathrm{t}$, deste modo, diminuir probabilidade de formação de zona inativa $[1,6,7]$;

- Maior Taxa de substituição do carvão: aumento do teor de carbono fixo, com matéria volátil do blend de carvão entre 15 a 25\% [1];

- Maior Eficiência de Combustão: menor umidade de sopro, aumento de Temperatura de Sopro, distribuição homogênea da Temperatura de Chama ao redor do forno (controle do $\mathrm{PCl}$ ), utilização de dupla lança de $\mathrm{PCl}$, diferentes tipos de lança, aumento de Enriquecimento de Oxigênio $\left(E_{2}\right)$ $[1,2,4,7]$

- Controle de Processo: definição dos parâmetros de sopro, controle da velocidade do sopro, controle do volume de gás (balanço entre volume de sopro e EO 2$)[1,2,7]$;

- Distribuição de Carga: ajustes para reduzir desvios de permeabilidade, aumentar rendimento de gás, estabilidade da marcha central, controle de zona de inativa e perdas térmicas [1,2];

- Menor teor de silício do gusa: maior pressão de topo, menor atividade da sílica na escória (menor input via carga metálica, cinza do coque e do carvão) [1].

- Tecnologias: câmera do topo, câmera de ventaneira, modelos de distribuição, modelo matemático de processo $[1,11]$.

O presente trabalho visa demonstrar a aplicação de alguns destes conceitos teóricos e alternativas para obtenção de altas taxas de PCl (redução de CR e custos) nos altos fornos da ArcelorMittal Tubarão a partir de 2014, mesmo em meio ao desafiador cenário atual de degradação da qualidade de matérias-primas (aumento de finos e impurezas). 


\section{MATERIAIS E MÉTODOS}

O projeto consistiu em basicamente estruturar as ações necessárias para obter a meta de Coque Rate abaixo de 298 kg/t. Para isso, várias reuniões e atividades foram realizadas para divulgar o projeto e promover o desenvolvimento de um novo modelo mental desafiador de operação, processo, manutenção e gestão por todas as áreas direta e indiretamente envolvidas (Alto Forno, Coqueria, Sinterização, Utilidades, Aciaria, fornecedores, contratadas), de forma mais integrada.

$\mathrm{Na}$ parte técnica, realizou-se benchmarking em empresas do grupo para identificar oportunidades de melhorias, boas práticas e investimentos. Desta forma, no segundo semestre de 2014 foi projetado o plano de redução de Coque Rate até atingir a meta de CR298 em dezembro de 2016, conforme Figura 3. Para isto, traçou-se um plano detalhado com ações e KPls (parâmetros) diversos para as áreas envolvidas, abrangendo qualidade e abastecimento de matérias-primas para os altos fornos, peneiramento, estabilidade de equipamentos, estabilidade de processo, revisão de padrões, práticas e controles operacionais.

Durante todo o desenvolvimento, efetuou-se o acompanhamento semanal dos KPIs, com devidas atualizações e revisões. Reuniões mensais e específicas também foram necessárias para acompanhamento e discussão da evolução do projeto.

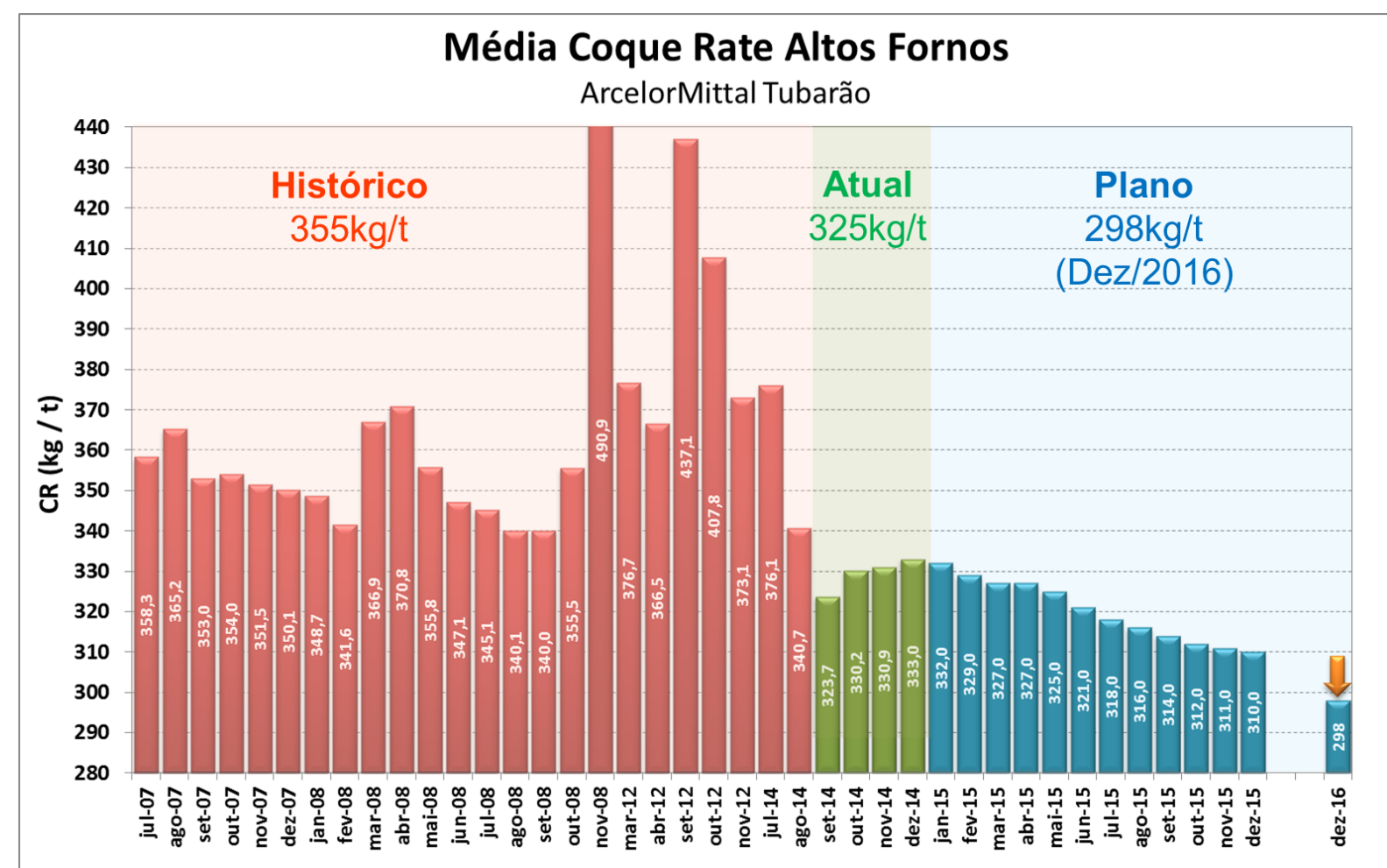

Figura 3. Média mensal do Coque Rate ponderado dos Altos Fornos e plano do projeto CR298.

\section{RESULTADOS E DISCUSSÃO}

A empresa ArcelorMittal Tubarão é uma usina siderúrgica integrada a qual possui três altos fornos e que estão em operação. As principais características destes estão descritas na Tabela 1. 
Tabela 1. Principais especificações dos altos fornos da ArcelorMittal Tubarão.

\begin{tabular}{|c|c|c|c|}
\hline Especificações & AF1 & AF2 & AF3 \\
\hline Start-up & $30 / 11 / 1983$ & 01/07/1998 & $21 / 07 / 2007$ \\
\hline Blow-in campanha atual & 04/09/2012 & $17 / 03 / 2012$ & 06/07/2014 \\
\hline Capacidade nominal & $3,28 \mathrm{Mt} / \mathrm{ano}$ & $1,20 \mathrm{Mt} / \mathrm{ano}$ & $2,80 \mathrm{Mt} / \mathrm{ano}$ \\
\hline Volume Interno & $4540 \mathrm{~m}^{3}$ & $1555 \mathrm{~m}^{3}$ & $3617 \mathrm{~m}^{3}$ \\
\hline Volume de Trabalho & $4111 \mathrm{~m}^{3}$ & $1374 \mathrm{~m}^{3}$ & $3126 \mathrm{~m}^{3}$ \\
\hline Diâmetro do Cadinho & $14,1 \mathrm{~m}$ & $8,0 \mathrm{~m}$ & $12,5 \mathrm{~m}$ \\
\hline № Furos de Gusa & 4 & 2 & 4 \\
\hline № Ventaneiras & 38 & 22 & 34 \\
\hline Refrigeração & Staves & $\begin{array}{c}\text { Staves (corpo) } \\
\text { Jaqueta (cadinho) }\end{array}$ & Staves \\
\hline Regeneradores & 4 - Comb. Externa & 3 - Comb. Interna & 3 - Comb. Interna \\
\hline Temperatura de Sopro & 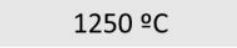 & $1250 \stackrel{\circ}{ } \mathrm{C}$ & $1250 \stackrel{\circ}{ } \mathrm{C}$ \\
\hline Topo & Bell-Less & Bell-Less & Bell-Less \\
\hline Pressão do Topo & $2,5 \mathrm{~kg} / \mathrm{cm}^{2}$ & $1,7 \mathrm{~kg} / \mathrm{cm}^{2}$ & $2,5 \mathrm{~kg} / \mathrm{cm}^{2}$ \\
\hline
\end{tabular}

Durante o ano de 2014, com o retorno do AF3 à operação no $2^{\circ}$ semestre, houve uma necessidade maior de redução de consumo de coque para a redução dos custos operacionais. Com isso, foi realizado um benchmarking técnico-operacional com empresas do grupo ArcelorMittal, permitindo a identificação de oportunidades de melhorias que pudesse viabilizar o processo de redução de $C R$ e o aumento de PCR de forma sustentável.

Construiu-se um plano detalhado com ações para todas as áreas envolvidas e com acompanhamento de parâmetros (KPls) que assegurassem 0 alcance desses resultados. Conforme descrito anteriormente, essas ações abrangeram tanto desenvolvimentos técnicos, capacitação de pessoas, definições de controles operacionais, estabilidade de equipamentos, controle de qualidade das matériasprimas e gestão de forma integrada. Desta forma, foi possível garantir a redução de CR e elevação de PCR em cada um dos três altos fornos, com resultados melhores do que a meta planejada, conforme mostrado nas Figura 4, Figura 5, Figura 6, Figura 7, Figura 8 e Figura 9. Nestes gráficos, estão destacados, em cor mais escura, também o recorde histórico de CR de cada alto forno.

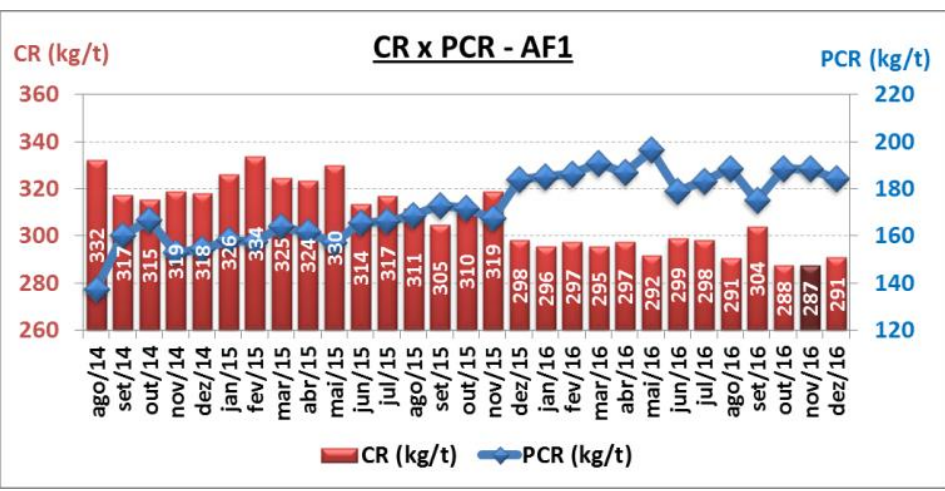

Figura 4. Média mensal de CR e PCR do AF1 após projeto CR298

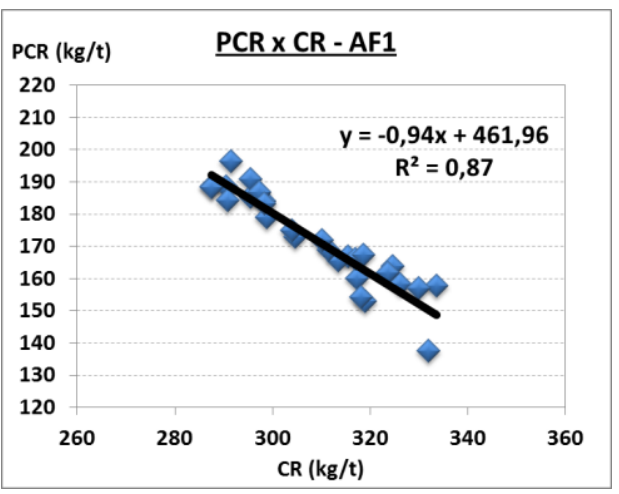

Figura 5. Correlação: CR e PCR do AF1. 


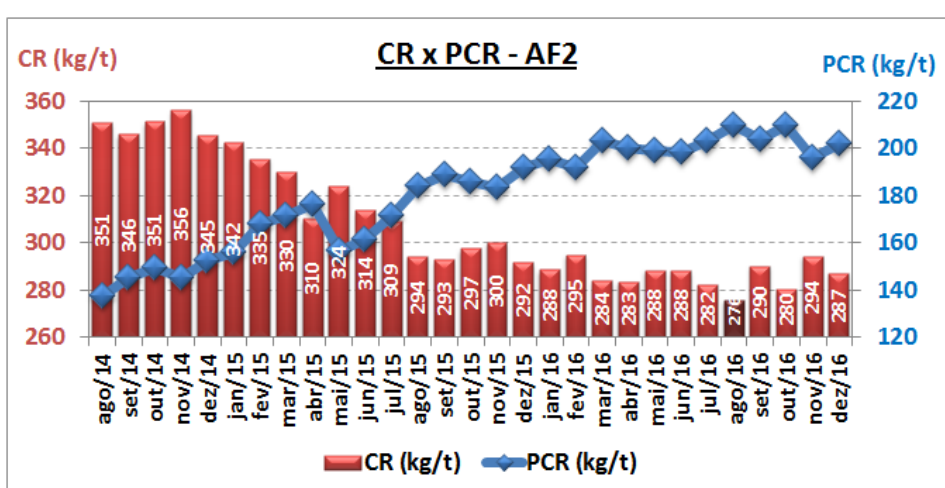

Figura 6. Média mensal de CR e PCR do AF2 após projeto CR298

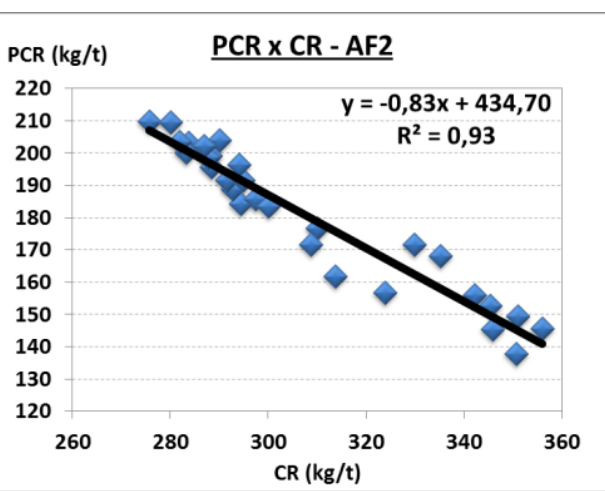

Figura 7. Correlação: CR e PCR do AF2.

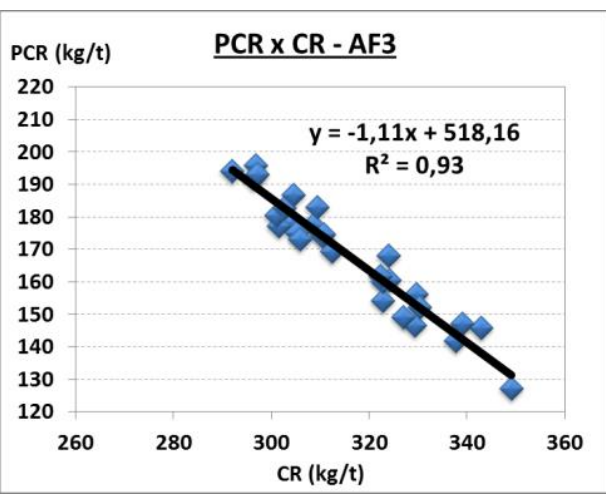

Figura 9. Correlação: CR e PCR do AF3.

Figura 8. Média mensal de CR e PCR do AF3 após projeto CR298

Além dos resultados de cada alto forno, tem-se as médias ponderadas de CR, PCR, EO2 e FR. A Figura 10 e a Figura 11 mostram o aumento do PCR e EO2 médios dos fornos, evidenciando a necessidade de ajustes da planta os quais permitiram 0 aumento do EO2 fornecido, visando controle da temperatura de chama e a eficiência de combustão do carvão para operação com CR mais baixo. Em alguns momentos, realizou-se operação com CR baixo e EO2 baixo (menor que 5,5\%) devido controle de produção de gusa por razões diversa (exemplo: aciaria).

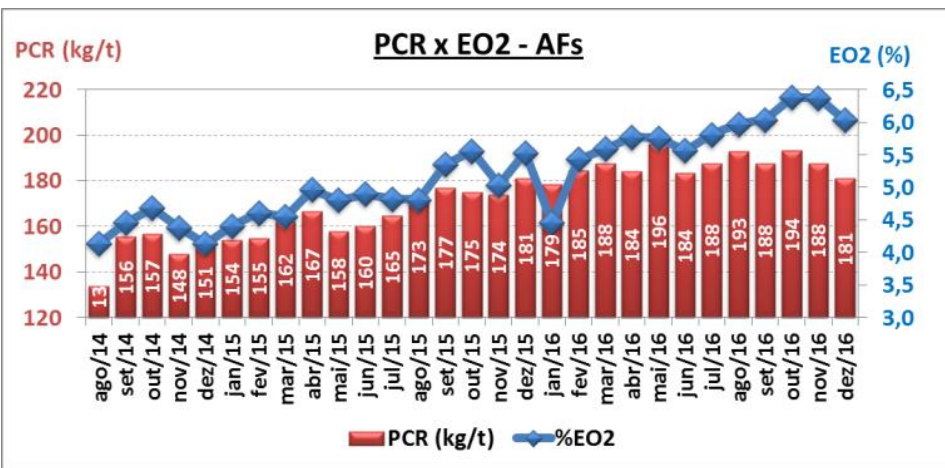

Figura 10. Média mensal de PCR e EO2 do AF3 após o projeto.

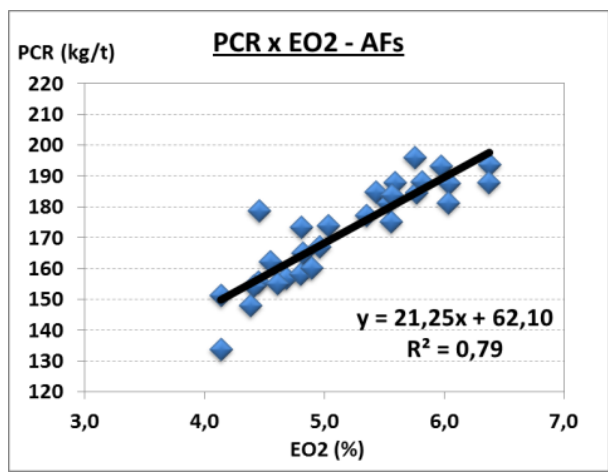

Figura 11. Correlação: PCR e EO2 do AF3

A Figura 12 e Figura 13 mostram a realização do projeto CR298, apresentando resultados melhores do que o planejado. A meta era obter $298 \mathrm{~kg} / \mathrm{t}$ na média ponderada dos fornos, em dezembro de 2016. Em fevereiro e março de 2016 já foi possível atingir valores próximos de 298,3 kg/t, e em maio, alcançou-se CR de 291,3 $\mathrm{kg} / \mathrm{t}$. Além disso, um fator importante foi a manutenção do FR abaixo de $490 \mathrm{~kg} / \mathrm{t}$, apesar da grande redução de $\mathrm{CR}$, mesmo apresentando baixa correlação entre 0 
CR e o FR (Figura 13), permitindo, portanto, a sustentabilidade econômica do projeto e a projeção de se reduzir ainda mais as metas de CR.

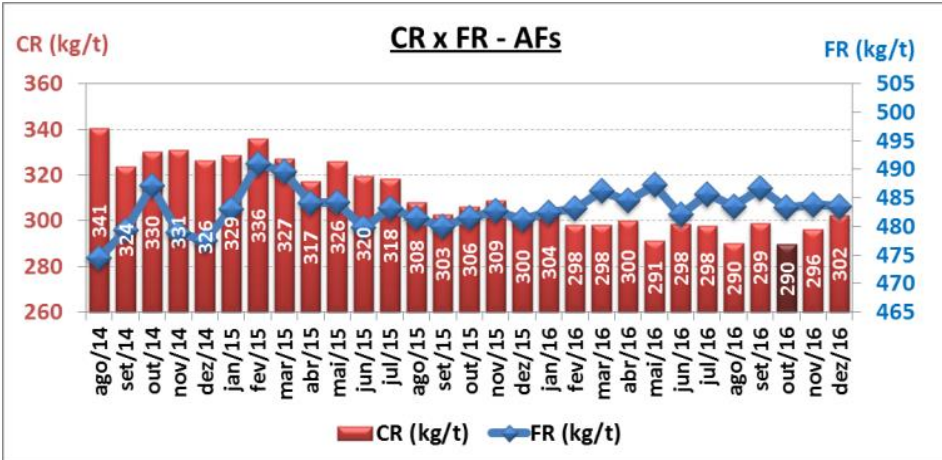

Figura 12. Média de CR e PCR dos altos fornos após o projeto.

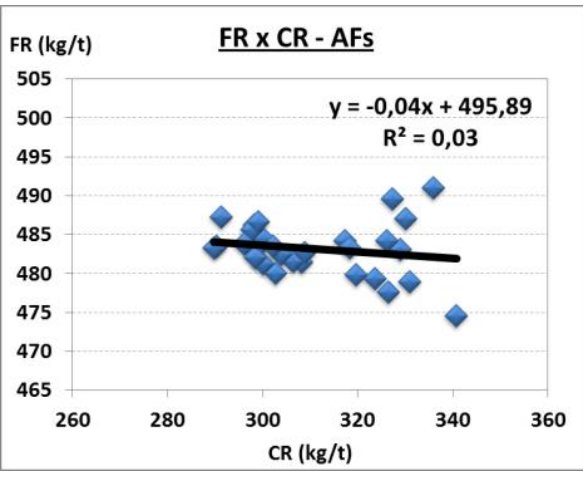

Figura 13. Correlação: CR e FR dos fornos

Conforme esperado, com a redução de CR e aumento de PCR, ocorreu a elevação da taxa de pó contido no gás BFG do topo dos altos fornos (pó do coletor) devido menor eficiência de combustão do carvão (principalmente abaixo de $300 \mathrm{~kg} / \mathrm{tg}$ de $\mathrm{CR}$ ), conforme mostrado na Figura 14 e Figura 15. Porém, alguns momentos de produção reduzida (EO2 baixo) ao longo do ano também impactaram nesta geração.

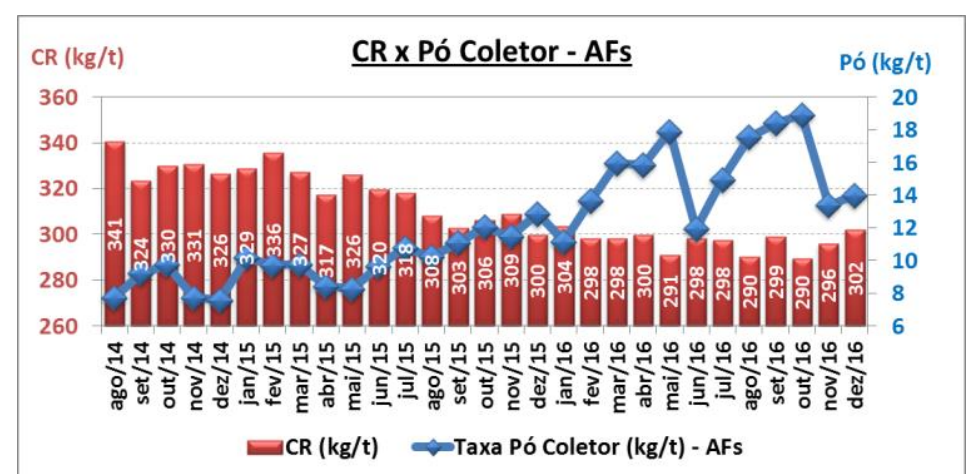

Figura 14. Média de CR e Taxa de Pó dos altos fornos.

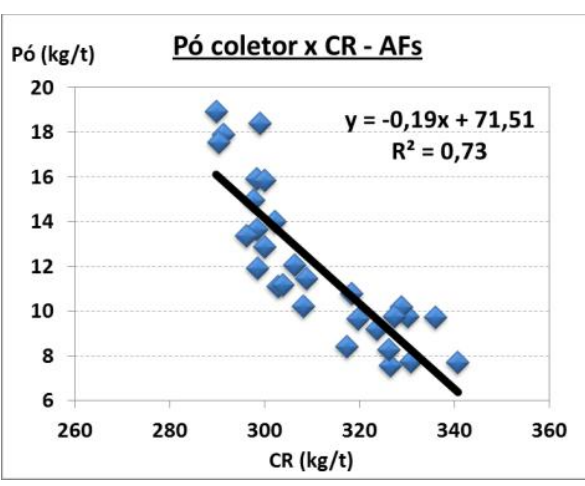

Figura 15. Correlação: CR e Pó dos fornos

Para amenizar estas perdas, outros fatores contribuíram para manter o FR baixo mesmo com a redução de CR. Por exemplo, conforme mostrado na Figura 16 e Figura 17, foi possível manter volume de escória (Slag Rate - SR) abaixo de 250 $\mathrm{kg} / \mathrm{t}$, permitindo também aumento de produtividade (próximo de 2,20 $\mathrm{t} / \mathrm{d} / \mathrm{m}^{3}$ Volume Interno).

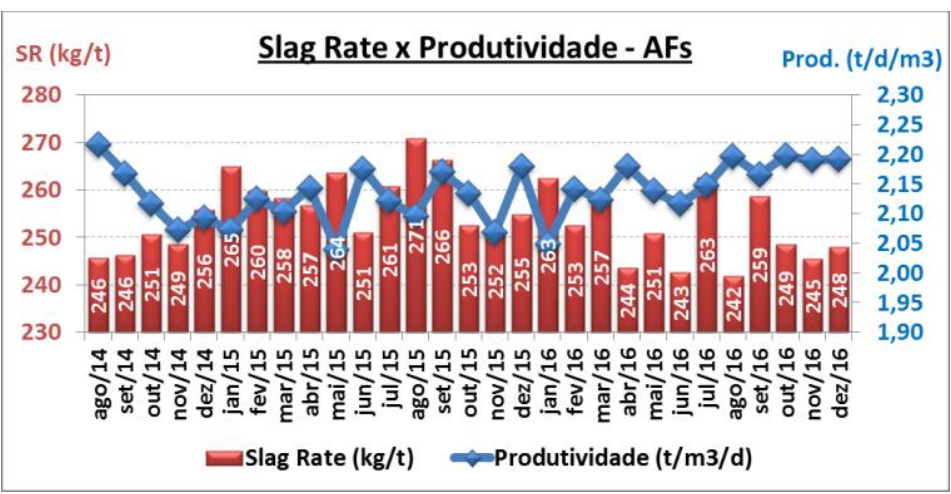

Figura 16. Média de Slag Rate e Produtividade dos fornos.

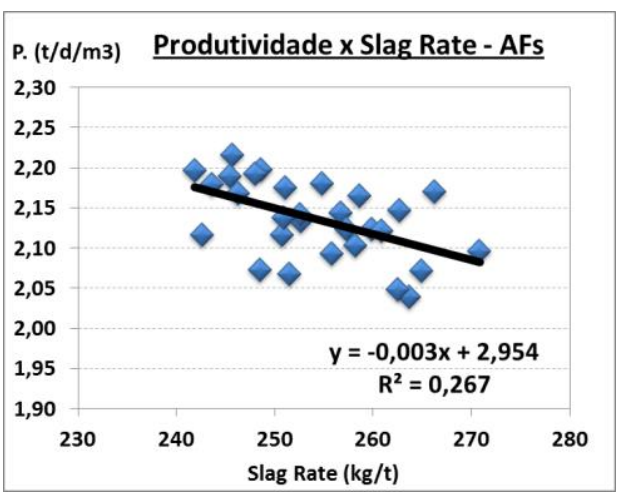

Figura 17. SR e produtividade dos fornos 
Outro fator que contribuiu para o resultado foi a redução da umidade do coque nos altos fornos. A Figura 18 e Figura 19 evidenciam o melhor controle e otimização do abastecimento de coque, permitindo não só menor umidade, mas também menor carregamento de finos nos altos fornos.

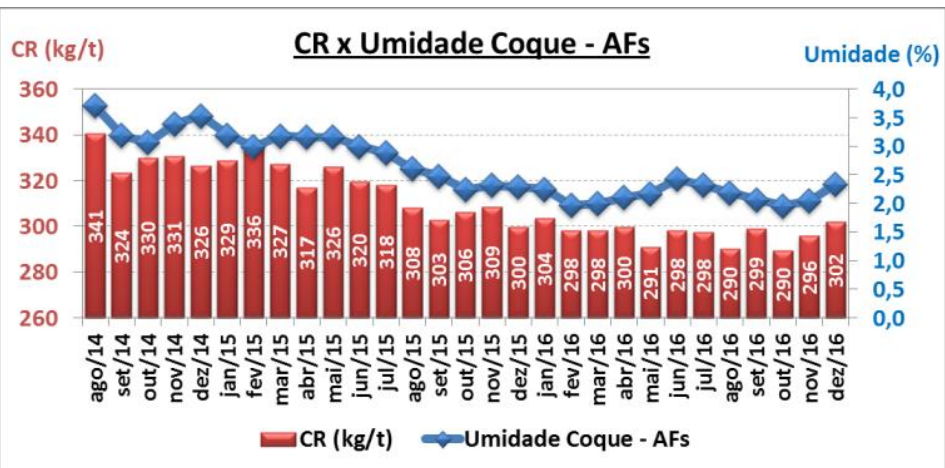

Figura 18. Média de CR e Umidade de Coque dos fornos.

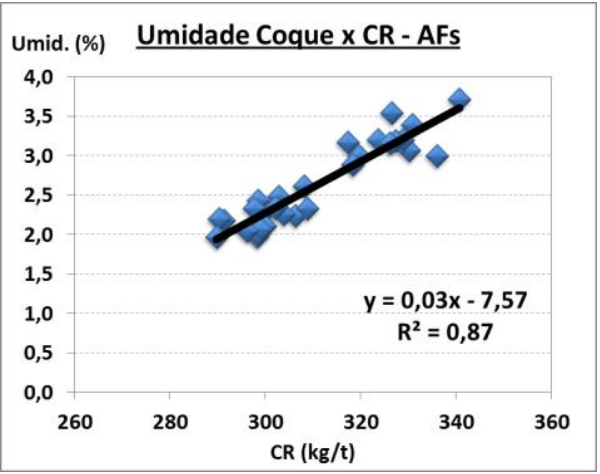

Figura 19. CR e umidade dos fornos

Comprovando as referências teóricas, também foi possível observar correlação entre a redução do input de álcalis e de zinco com redução de CR nos altos fornos, conforme evidenciado na Figura 20, Figura 21, Figura 22 e Figura 23.

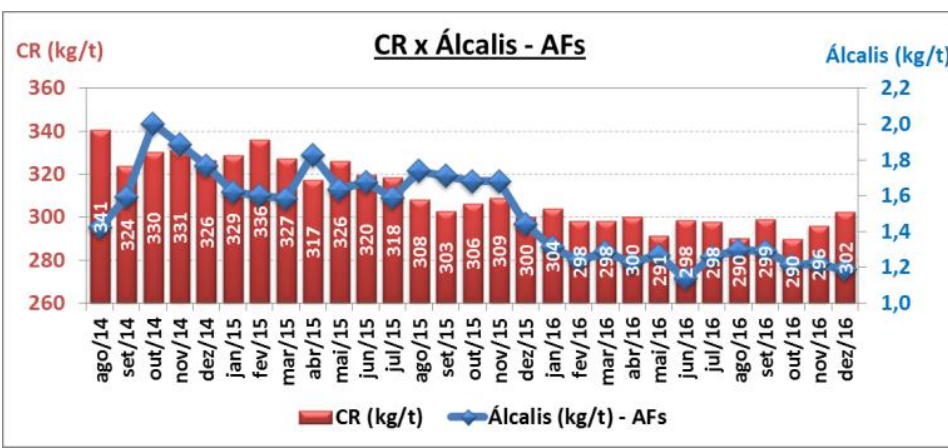

Figura 20. Média de CR e input de Álcalis nos fornos.

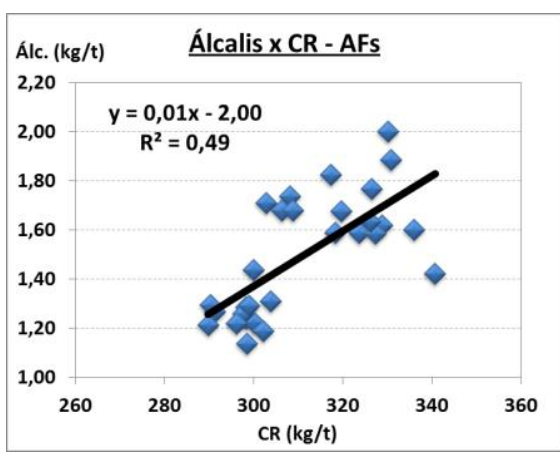

Figura 21. CR e input de álcalis nos AFs

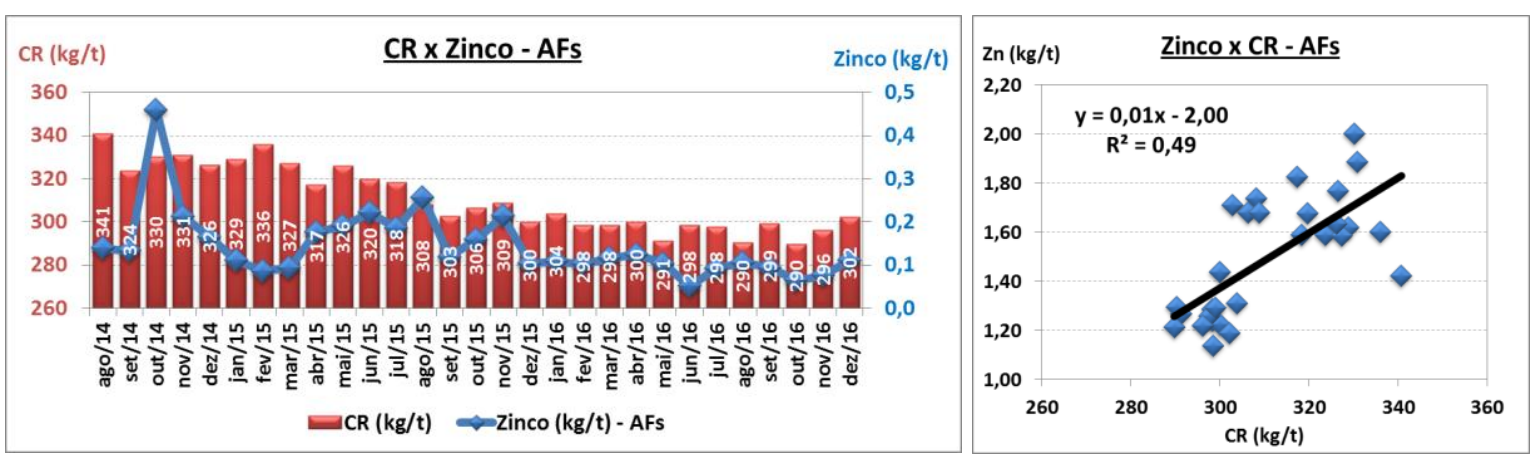

Figura 22. Média de CR e input de Zinco nos fornos.

Figura 23. CR e input de Zinco nos fornos

Como uma das premissas mais fundamentais para as altas taxas de $\mathrm{PCl}$, o coque manteve-se com parâmetros adequados de qualidade, conforme Figura 24 e Figura 25. Para o coque próprio AMT (CDQ), foi mantido o CSR e ocorreu ligeiro aumento do DI. Para o coque SOL (SUNCOKE: CWQ), a qualidade foi mantida com DI em torno de $86 \%$ e CSR de $65,5 \%$. Operacionalmente, o Coque CDQ é consumido no AF1 e AF2, enquanto o Coque SOL é consumido no AF3. 


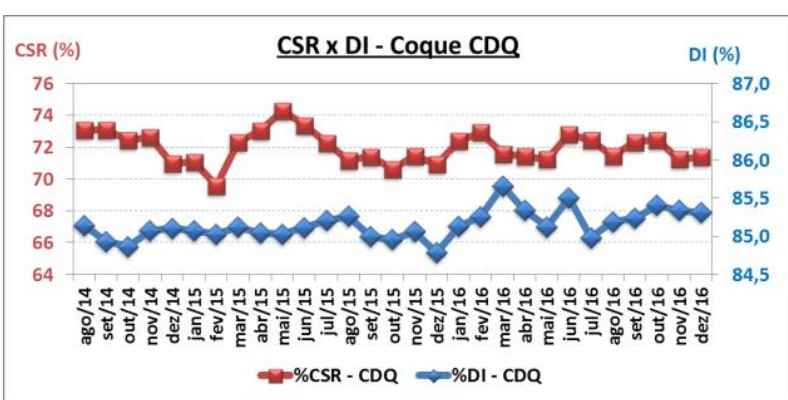

Figura 24. Média mensal de DI e CSR do Coque CDQ

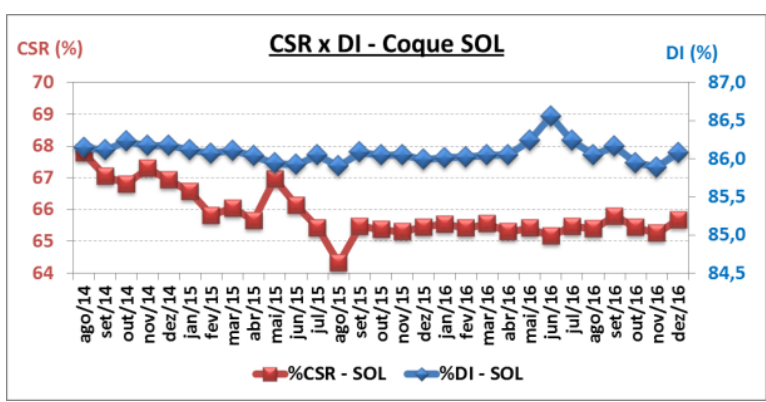

Figura 25. Média mensal de DI e CSR do Coque SOL

Ao longo do tempo, foram realizadas revisões de padrões operacionais, com controles de processo mais restritos, de acordo com os parâmetros operacionais definidos para acompanhamento. Além desses ajustes e do melhor controle de matérias-primas, ajustes de distribuição de carga também foram realizados para permitir o controle do rendimento de gás do alto forno (ETA CO) e redução de CR. De acordo com as próprias referências citadas, objetivou-se aumento do ETA CO e estabilização do fluxo de gás mediante o equilíbrio entre fluxo central (alimentação de coque no cadinho e retirada de finos) e fluxo periférico (controle de permeabilidade, rendimento e formação de zonas inativas). A Figura 26 e Figura 27 mostram a importância do melhor rendimento de gás e estabilidade do controle de perda térmica dos staves (carga térmica) para a redução de CR.

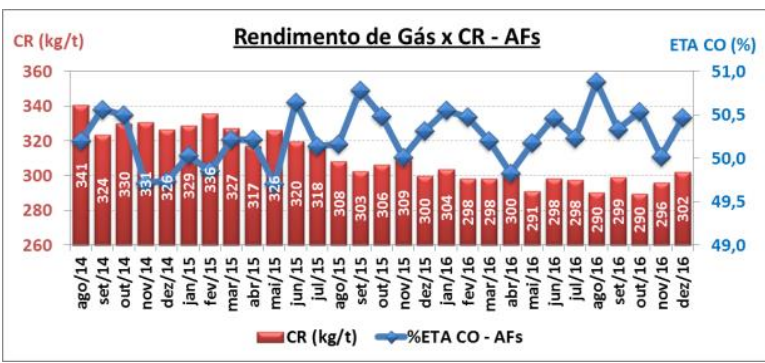

Figura 26. CR e Rendimento de gás dos altos fornos.

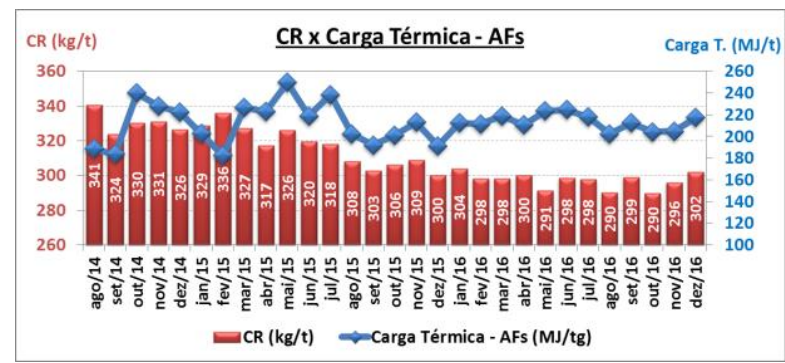

Figura 27. CR e Carga Térmica dos staves dos fornos

Nos últimos anos também ocorreu a redução da taxa de paradas não-programadas dos altos fornos (UMSR) através de medidas de gestão de manutenção, aquisição e desenvolvimento de equipamentos e serviços de maior confiabilidade, permitindo que os altos fornos mantenham operação normal por mais tempo de modo a facilitar o processo de redução de CR. Nota-se na Figura 28 e Figura 29 que, apesar de alguns eventos pontuais, a taxa de paradas não-programadas permaneceu abaixo de $1,0 \%$ nos últimos anos três anos.

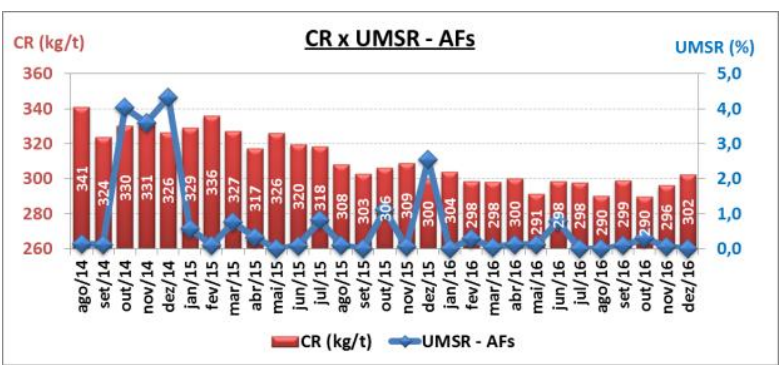

Figura 28. CR e Taxa de Parada não-programada.

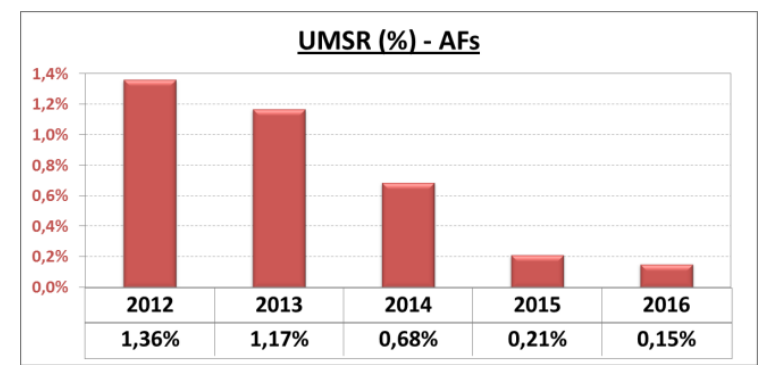

Figura 29. Média anual: taxa de parada não-programada

Portanto, o projeto CR298 permitiu que os altos fornos da ArcelorMittal Tubarão alcançassem resultados históricos de CR, conforme se observa na Figura 30. As 
médias ponderadas de CR obtidas no ano de $2015(316,4 \mathrm{~kg} / \mathrm{t})$ e no ano de 2016 (297,0 kg/t) foram os valores mais baixos de CR desde o start-up da usina em 1983. Assim sendo, mesmo com a grande redução de CR, não foi observada uma significativa elevação do FR, mantendo-se em patamares adequados: $483,4 \mathrm{~kg} / \mathrm{t}$ em 2015 e 484,4 kg/t em 2016.

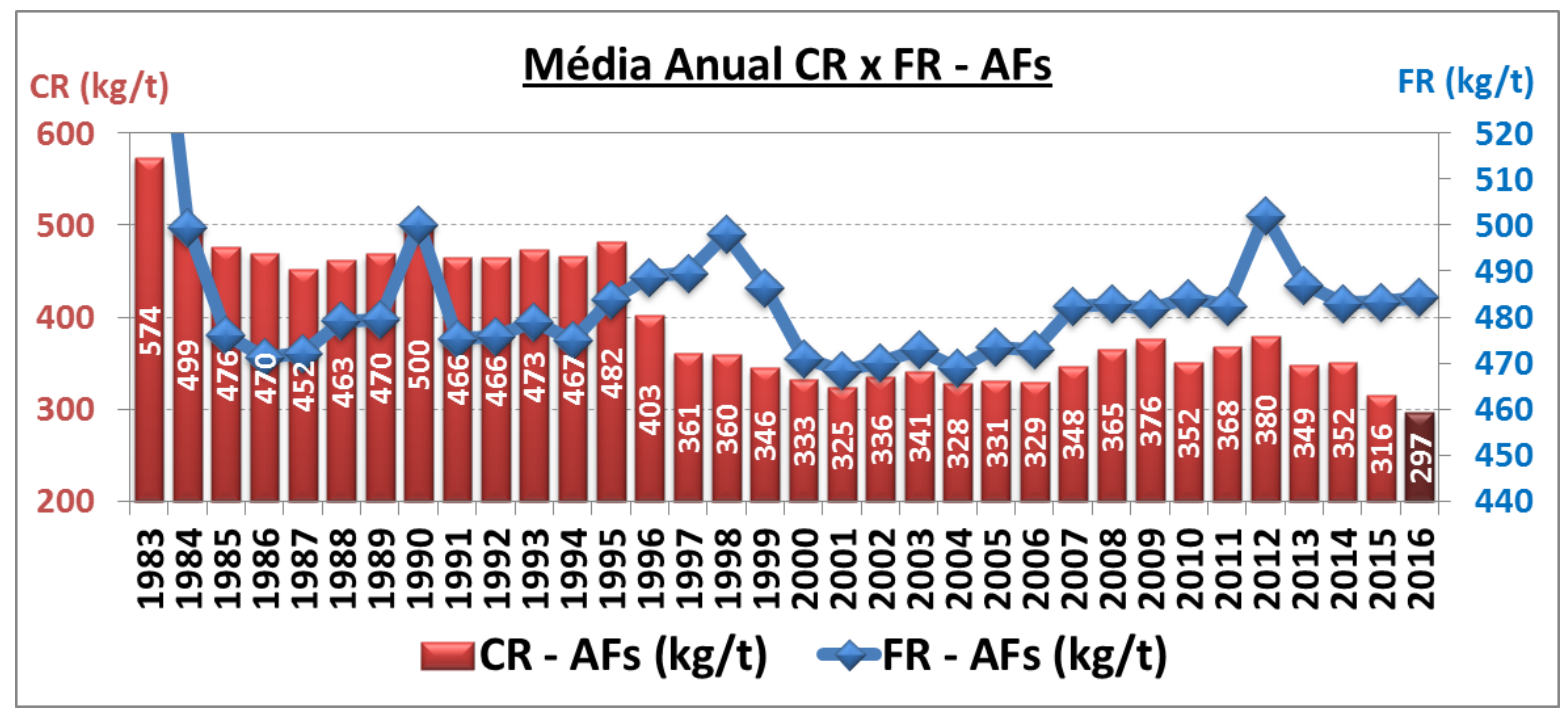

Figura 30. Média ponderada anual de CR e FR dos altos fornos desde o start-up da usina (1983).

O recorde anterior de CR anual era de $324,8 \mathrm{~kg} / \mathrm{t}$ em 2001, quando havia somente 0 AF1 e o AF2 em operação, conforme resultados resumidos na Tabela 2.

Tabela 2. Principais recordes obtidos nos altos fornos da ArcelorMittal Tubarão desde start-up (1983).

\begin{tabular}{|c|c|c|c|c|c|c|c|c|c|c|c|c|c|}
\hline \multirow{2}{*}{ RECORDES } & \multicolumn{2}{|c|}{ ALTO FORNO 1} & \multicolumn{4}{|c|}{ ALTO FORNO 2} & \multicolumn{3}{|c|}{ ALTO FORNO 3} & \multicolumn{4}{|c|}{ ALTOS FORNOS } \\
\hline & $1^{\circ}$ camp & $2^{\circ}$ camp & \multicolumn{2}{|c|}{$1^{2}$ fase } & \multicolumn{2}{|c|}{$2^{\mathrm{a}}$ fase } & \multicolumn{2}{|c|}{$1^{1}$ fase } & $2^{\mathrm{a}}$ fase & \multicolumn{2}{|c|}{$1^{2}$ fase } & \multicolumn{2}{|c|}{$2^{a}$ fase } \\
\hline CR - Mês (kg/t) & 320,4 Fev/05 & 287,5 Nov/16 & 285,5 & Mai/01 & 275,8 & Ago/16 & 324,4 & Out09 & 292,1 Mai/16 & 290,3 & Ago/16 & 289,8 & Out/16 \\
\hline CR - Ano (kg/t) & $332,3 \quad 2006$ & 294,4 & 296,0 & 2010 & 286,0 & 2016 & 346,9 & 2010 & $302,2 \quad 2016$ & 324,8 & 2001 & 297,0 & 2016 \\
\hline CR - Mínimo carregado $(\mathrm{kg} / \mathrm{t})$ & 314,0 Fev/05 & $279,0 \quad$ Ago/16 & 275 & Mai/01 & 270 & Ago/16 & 318,0 & Abr/10 & 279,0 Ago/16 & 318,0 & Abr/10 & 279,0 & Ago/16 \\
\hline Large CR - Mês (kg/tg) & 243,8 Fev/05 & 242,0 Out 16 & 246,6 & Jul/03 & 240,2 & Ago/16 & 254,7 & Dez/11 & 250,5 Out 16 & 274,5 & 2015 & 255,9 & 2016 \\
\hline
\end{tabular}

\section{CONCLUSÃO}

Mediante a consecução do plano de ação do projeto CR298, os Altos Fornos da ArcelorMittal Tubarão realizaram a elevação das taxas de injeção de carvão $\mathrm{PCl}$, com consequente redução de Coque Rate para valores históricos e melhores do que o planejado. No final de 2014, a meta projetada era de obter $298 \mathrm{~kg} / \mathrm{t} \mathrm{em} \mathrm{Dezembro}$ de 2016. Porém, em Maio de 2016 já foi possível atingir média mensal de 291,3 kg/t, permitindo, em 2016, média anual de 297,0 kg/t de Coque Rate e 484,4 kg/t de Fuel Rate. Vários fatores foram determinantes para estes resultados, tais como: estruturação de novo modelo mental de operação, processo, manutenção e gestão nas áreas envolvidas de forma integrada; desenvolvimento técnico e capacitação das pessoas; cumprimento de premissas técnicas; garantia de estabilidade no processo dos altos fornos. Portanto, este projeto desafiador proporcionou significativa redução de custos operacionais, assegurando sustentabilidade e competividade no mercado siderúrgico. 


\section{Agradecimentos}

A Deus, a ArcelorMittal Tubarão, aos familiares e amigos.

\section{REFERÊNCIAS}

1 Liu ZJ, Zhang JI, YANG TI. Low Carbon Operation of Super-Large Blast Furnaces in China. ISIJ International. 2015; 55 (6): 1146-1156.

2 Zhang S, Bi X, Theoretical consideration of problems relating to high coal rate injection into blast Furnaces. Ironmaking and Steelmaking. 2003; 30(6): 467474.

3 Ariyama T, Sato M, Nouchi T, Takahashi K. Evolution of Blast Furnace Process toward Reductant Flexibility and Carbon Dioxide Mitigation in Steel Works. ISIJ International. 2016; 56(10):1681-1696.

4 Oliveira RP, Manetta H, Cruz JG, Maia MES, Gomes DA, Monteiro MR, Costa GB. Operação dos Altos-Fornos da V\&M do Brasil com altas taxas de injeção de carvão pulverizado. Tecnologia em Metalurgia e Materiais. São Paulo. 2008; 5(2): 105-110.

5 Ishii, K. Advanced Pulverised Coal Injection Technology and Blast Furnace Operation, Pergamon, publishers. 2000

6 Sathler F. Estudo descritivo sobre os principais fundamentos teóricos e práticos do procedimento de Blowdown de Altos Fornos. Dissertação (Graduação em Engenharia Metalúrgica) - Instituto Federal do Espírito Santo (IFES), Vitória. 2013.

7 Chung JK, Hur NS. Tuyere Level Coke Characteristics in Blast Furnace with Pulverized Coal Injection. ISIJ International. 1997; 37(2):119-125.

8 An JY, Seo JB, ChoiJH, Lee JH, Kim H. Evaluation of Characteristics of Coke Degradation after Reaction in Diferrent Conditions. ISIJ International. 2016; 56(2):226-232.

9 Lüngen HB, Noldin Jr JH, Schmöle P. Trens in Iron-Making given the New Reality of Iron Ore and Coal Resources. METEC \& 2nd ESTAD. Dusseldorf. 2015.

10 Matsui Y, Tanaka M, Sawayama M, Kitano S, Imai T, Goto A. Analyses on dynamic solid flow in blast furnace lower part by deadman shape and raceway depth measurement. ISIJ International. 2005; 45(10):1445-1451.

11 Bilik J, Kret J, Beer H. Application of the Simulation mathematical models for decreasing of the Blast Furnace Fuel Rate. Acta Metallurgica Slovaca. 1998; 2(1): 61-70. 